\section{A imagem corporal}

Simone M. Castilho, Santo André, Editora ESETec Editores Associados, 2001, 100 páginas.

O tema Imagem Corporal é de interesse geral, pois cada vez mais, as pessoas têm a sua identidade ligada a essa imagem, muitas vezes, confundindo-a com identidade. A preocupação com a aparência é fato na nossa sociedade e, sendo tão preponderante, leva as pessoas a se preocuparem excessivamente com ela. Como diz Lotufo Neto no prefácio desse livro, as distorções da imagem corporal estão associadas a diversos transtornos psiquiátricos. Só por ter esse tema como foco, valeria a leitura do trabalho. Mas o texto traz muito mais.

$\mathrm{Na}$ primeira parte, é destacado o conceito do corpo e do belo, abordando as diferentes percepções da imagem corporal ao longo da história, em diferentes culturas. Ressalta-se que o belo está determinado pela cultura e pelo momento histórico. Na segunda parte, são apresentados o conceito de imagem corporal e seu desenvolvimento. Não necessariamente representa o reflexo do espelho, mas como a autora diz: "ter uma boa aparência não significa ter uma imagem corporal positiva, a imagem corporal é, na verdade, um estado de espírito". Nesse tópico, as conseqüências da imagem corporal negativa são ressaltadas, inclusive as cirurgias estéticas, muitas vezes desnecessárias. A autora termina o trecho com uma proposta de avaliação, muito útil ao profissional que está iniciando seu trabalho na área.

Na terceira parte, o tratamento é enfocado com base na abordagem cognitivo-comportamental, dando dicas importantes para o terapeuta, como registros, por exemplo. Inicialmente, o foco cognitivo é apresentado e são destacadas as crenças sobre aparência, fornecendo praticamente um check list, onde se pode verificar qual crença o paciente apresenta sobre a imagem corporal, identificando o processo de aprendizagem aí inserido e auxiliando esse paciente a transformá-las em crenças funcionais. São apresentadas também, as distorções cognitivas, bem como as técnicas para modificá-las. Em seguida, é discutido o foco comportamental e as técnicas que essa abordagem

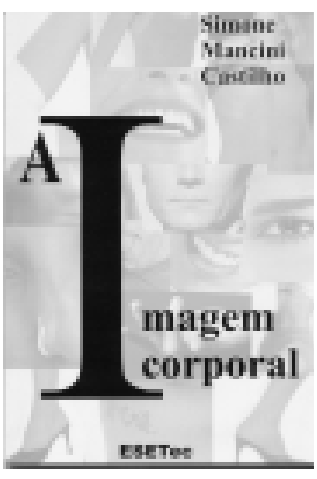
desenvolve, também enfatizando os comportamentos de esquiva e os rituais de preocupação com a aparência.

O livro termina com uma breve descrição das patologias que podem ter a imagem corporal como um sintoma associado ou como o cerne da doença. Descrição essa, que serve como introdução para os estudantes da área da saúde a esse tema tão complexo - as patologias psiquiátricas.

O texto é claro e objetivo, o que torna a leitura agradável e favorece a compreensão. Sendo a autora estudiosa desse tema há vários anos, a obra só tem a acrescentar em uma área pobre em trabalhos na língua portuguesa.

Mariangela Gentil Savoia

Setor de Psicologia do Centro de Atenção Integrada à Saúde Mental da Irmandade da Santa Casa de Misericórdia de São Paulo

Ambulatório de Ansiedade do Instituto de Psiquiatria do HC - FMUSP Instituto de Psicologia da USP 